\title{
Servant leadership and its effects on IT project success
}

\section{Mark Harwardt ${ }^{\text {a* }}$}

${ }^{a}$ Hochschule für angewandtes Management, Germany

CH R O I C L E A B T T A C T

Article history:

Received: May 252019

Received in revised format: June 212019

Accepted: July 212019

Available online:

July 212019

Keywords:

Leadership

Servant Leadership

Effects

Project management

Success criteria

Success dimensions

Project evaluation

\begin{abstract}
Servant Leadership is well known as an employee-oriented leadership style which is used by several major corporations. This work investigates the effects that Servant Leadership may have on the success of Information Technology (IT) projects. To estimate these effects via structural equation modelling (SEM) this study is based on already established models: the model of Servant Leadership developed by Van Dierendonck and Nuijten and the model of IT project success developed by Harwardt. Three of the Servant Leadership dimensions have positive impact on the success dimensions IT project. The Servant Leadership Dimension Accountability has a positive impact on the dimensions Project management success, Perception success and Result success. Authenticity has a positive impact on Project management success and Result success, whereas Forgiveness affects only Result success.
\end{abstract}

C 2020 by the authors; licensee Growing Science, Canada.

\section{Introduction}

Projects, as a form of cooperation, have established over the past years and their significance within companies has steadily increased (Jessen, 2002). Due to the great operational and strategical relevance of IT within companies, this applies especially for IT projects (Schwalbe, 2013). The large number of studies dealing with the effect of leadership on the performance of teams or the effect of leadership on project success is thus not astonishing. Nevertheless, these studies are often limited to the project manager's leadership within the team. The effect of management leadership is not taken into consideration (Clarke, 2012). The type of leadership most focused on within the course of empirical studies analyzing the effect of leadership on the success of IT projects is Transformational Leadership (Clarke, 2012). Servant Leadership, like Transformational Leadership, is an employee-oriented type of leadership (Giampetro-Meyer et al., 1998; Hale and Fields, 20017; Irving and Longbotham, 2007) that has by now gained currency and is applied in large companies like Starbucks, Vanguard Investment Group, Southwest Airline and ID Industries (Bass \& Bass, 2008; Parris \& Peachey, 2013; Spears, 1995). Despite its large dissemination it can be stated that only a few empirical studies have been conducted about Servant Leadership. The focus was on the devel-

\footnotetext{
* Corresponding author.

E-mail address: mark.harwardt@,fham.de (M. Harwardt) 
opment of constructs and measurement models (Parris \& Peachey, 2013). Profound empirical research is thus missing and needed (Amin \& Kamal, 2016; Bass, B., 2000; Bass \& Bass, 2008; Parris \& Peachey, 2013).

Regarding the effects accredited to Servant Leadership it is surprising that this did not happen yet. In the following some of these effects are listed exemplarily:

- Servant Leadership establishes a strong relation between a servant leader and the followers; whereby a servant leader is someone who applies Servant Leadership as type of leadership. The application of Servant Leadership generates "employees' extra effort, employees' satisfaction, and perceptions of organizational effectiveness" (Barbuto \& Wheeler, 2006, S. 322).

- Trusting the servant leader and the servant-led organization creates an environment that can improve the cooperation in team (Garber et al., 2009; Irving and Longbotham, 2007).

- Servant Leadership can increase the employees' efficiency (Irving and Longbotham, 2007; Mayer et al., 2008; McCuddy \& Cavin, 2008; Parris \& Peachey, 2013)

- Servant Leadership can make companies profitable (Melrose, 1998).

This research aims at closing the gap in literature and conducting an empirical study on the effect of Servant Leadership. Therefore, the effect of Servant Leadership on the success of IT projects shall be presented in the following.

\section{Theoretical embedding}

\subsection{Servant Leadership}

In 1970, Robert K. Greenleaf published the essay The Servant as Leader. According to him, he got the idea that a true leader is, in fact, a servant after reading Hermann Hesses Journey to the East. In this novel the alleged servant Leo turns out to be the true leader of a group the narrator heads to the Orient with (Hesse, 2003). In his essay Greenleaf states that a leader consciously chooses to serve and gives priority to the needs of those led: "It begins with the natural feeling one wants to serve, to serve first. Then conscious choice brings one to aspire to lead. That person is sharply different from one who is leader first... The difference manifests itself in the care taken by the servant-first to make sure that other people's highest priority needs are being served. The best test, and difficult to administer, is this: Do those served grow as persons? Do they, while being served, become healthier, wiser, freer, more autonomous, more likely themselves to become servants? And, what is the effect on the least privileged in society? Will they benefit or at least not be further deprived?" (Greenleaf, 1970, S.7). By focusing on the led they shall grow as humans and employees and pay back the trust put in them with increased performance and creativity (Greenleaf, 1970).

Greenleaf (1970) himself describes his work as not being based on logic. His ideas and theories on Servant Leadership are thus not a result of empirically designed studies but are rather based on his own experiences and reflections (Greenleaf, 1970; Van Dierendonck, 2011). Greenleaf (1970) did not give an exact definition of Servant Leadership in his work, but rather describes the behavior characterizing a Servant Leader as well as its possible influence on the followers (Smith et al., 2004). Russel and Stone (2002) comment on this: ,, Unfortunately, the literature regarding servant leadership is rather indeterminate, somewhat ambiguous, and mostly anecdotal" (Russel and Stone, 2002, p. 145). It is thus not astonishing that most researchers concerned with Servant Leadership create their own models and definitions for their research (Van Dierendonck, 2011).

Except for the quote from Greenleaf mentioned earlier in this paragraph, the definitions from Spears (1995) and Laub (1999) are most often referred to in the course of studies on Servant Leadership (Parris and Peachey, 2013). Spears was a former executive director of the Greenleaf Center for Servant Leadership and thus highly qualified to phrase ideas on Servant Leadership (Van Dierendonck, 2011). At that he developed the image of a Servant Leader having ten characteristics: 
Listening, Empathy, Healing, Awareness, Persuasion, Conceptualization, Foresight, Stewardship, Commitment to the growth of people and Constitution of a community (Spears, 1995; Spears, 2004). Laub (1999), instead, defined a Servant Leader as somebody who appreciates people, helps people develop, builds a community, shows authenticity, provides leadership and, at the same time, shares leadership. Based on this definition Laub (1999) developed a first corresponding measurement model of Servant Leadership.

In his literature review Van Dierendonck (2011) criticizes the legacy of Greenleaf(1970) as unqualified for a definition of Servant Leadership. He also criticizes the work of Spears $(1995 ; 2004)$ and Laub (1999): Referring to Laub (1999), he criticizes that the multidimensionality that labels Servant Leadership gets lost in his approach (Van Dierendonck, 2011). Spears (1995; 2004), on the other hand, had never refined his ideas to a tangible model, so that his ten characteristics had not been adequately operationalized (Van Dierendonck, 2011). Therefore, based on a comprehensive review of the existing literature on Servant Leadership and on interviews with Servant Leaders, Van Dierendonck and Nuijten (2011) developed a model of Servant Leadership that was subsequently operationalized and empirically tested. The final model by Van Dierendonck and Nuijten (2011) consists of eight dimensions:

- Empowerment ${ }^{1}$ describes the ability of a Servant Leader to empower people to do their work and evolve. The Servant Leader believes in the value of every single person.

- The dimension Accountability means that the followers are accountable for all achievements they can control themselves. Therefore, the followers need to know what is expected from them and the Servant Leader has to confer to them the responsibility for their tasks.

- Standing back signifies the ability of a Servant Leader to assign highest priority to the followers' interests and to grant them both the support needed and the appreciation of their work. The Servant Leader takes a back seat.

- Humility comprises the characteristic of Servant Leader to regard his own talents and abilities from an appropriate perspective and thus to admit that he, too, might make mistakes. A Servant Leader is aware of his own limits and weaknesses.

- The dimension Authenticity represents that the Servant Leader always presents himself consistently to his thoughts and feelings. The point here is to always express oneself in a professional environment.

- Courage refers to the ability of taking risks and trying new solutions. A Servant Leader hence questions even conventional procedure models within the organization.

- Forgiveness characterizes the extent to which a Servant Leader can forgive perceived mistakes and not pursue or transfer them to other situations. By this, a Servant Leader is enabled to generate an atmosphere of trust.

- Stewardship describes the ability of a Servant Leader to assume responsibility for the organization and to focus on serving, so that control and self-interest fade into the background. Servant Leaders are supposed to be role models, so that others may follow the lead.

Servant Leadership is associated with a multitude of impacts and positive effects that are listed exemplarily in Table 1. The essential summary is that the impacts of Servant Leadership, e.g. employee satisfaction, increased efficiency or commitment to the organization, result from the strong

\footnotetext{
${ }^{1}$ For the purpose of better differentiation the dimensions of Servant Leadership and the success dimensions and success criteria of IT projects are italicized in the following. This does not apply for tables and figures.
} 
focus on the employee and his needs as well as from the demand of a steady development of the followers.

\section{Table 1}

Effects of Servant Leadership

\begin{tabular}{|c|c|}
\hline Effects of Servant Leadership & Sources \\
\hline Servant Leadership takes leader and follower to a higher level of motivation and morality. & Andersen,2009; Hamilton, 2008 \\
\hline Servant Leadership increases employee satisfaction and thus reduces employee turnover. & Babakus et al., 2011 \\
\hline Servant Leadership creates a healthier environment in the organization for the followers. & Barbuto \& Wheeler, 2006 \\
\hline $\begin{array}{l}\text { Servant Leadership allows strong and serving relationships between Servant Leader and follow- } \\
\text { ers, thus generating employee satisfaction, enhanced perception of the organization's efficiency } \\
\text { and additional deployment of staff. }\end{array}$ & Barbuto \& Wheeler, 2006 \\
\hline $\begin{array}{l}\text { Trusting the Servant Leader and the servant-led organization creates an environment that can } \\
\text { improve the cooperation in team. }\end{array}$ & $\begin{array}{l}\text { Garber et al., 2009; Irving \& Longbotham, } \\
\qquad 2007\end{array}$ \\
\hline The efficiency of employees and teams can be increased by Servant Leadership. & $\begin{array}{l}\text { Irving \& Longbotham, 2007; Mayer et al., } \\
\text { 2008; McCuddy et al., 2008; Parris \& } \\
\text { Peachey, 2013; Taylor et al., } 2007\end{array}$ \\
\hline Servant Leadership improves the individual performance of the employees. & $\begin{array}{l}\text { Harwiki, 2013; Jarmillo et al., 2009; Liden } \\
\text { et al., } 2014\end{array}$ \\
\hline Servant Leadership can render organizations more productive and profitable. & Joseph and Winston, 2005; Melrose, 1998 \\
\hline $\begin{array}{l}\text { Servant Leadership creates a positive working atmosphere, which is correlated with the com- } \\
\text { mitment to the organization. This, in turn, has an impact on the employees' satisfaction. }\end{array}$ & $\begin{array}{l}\text { Cerit, 2009; Cerit, 2010; Chung et al., 2010; } \\
\text { Hale \& Fields, 2007; Mayer et al., 2008; } \\
\text { Neubert et al., } 2008\end{array}$ \\
\hline $\begin{array}{l}\text { The orientation towards growth and success of the employees is correlated positively to the } \\
\text { commitment to the organization. }\end{array}$ & Liden et al., 2008 \\
\hline $\begin{array}{l}\text { A servant-led environment generates the preconditions for justice and fair treatment, which are } \\
\text { again linked positively to equality. }\end{array}$ & Chung et al., 2010; Ehrhart, 2004 \\
\hline $\begin{array}{l}\text { Equality, rendered by Servant Leadership, promotes trust in the Servant Leader and the organi- } \\
\text { zation. }\end{array}$ & $\begin{array}{c}\text { Joseph \& Winston, 2005; Sendjaya \& Sar- } \\
\text { ros, } 2002\end{array}$ \\
\hline A positive correlation exists between Servant Leadership and the efficiency of a leader. & $\begin{array}{l}\text { Hale \& fields, 2007; Hu \& Bentler, 1998; Ir- } \\
\text { ving \& Longbotham, 2007; Neubert et al., } \\
\qquad 2008\end{array}$ \\
\hline Servant Leadership promotes and enables a culture of helping. & $\begin{array}{l}\text { Ehrhart, 2004; Garber et al., 2009; Hu and } \\
\quad \text { Liden, 2011; Walumbwa et al., } 2010\end{array}$ \\
\hline $\begin{array}{l}\text { The perception of Servant Leadership is positively correlated to the trust in leaders, in particular } \\
\text { by the communicative and supportive style of the management. }\end{array}$ & Joseph and Winston, 2005 \\
\hline $\begin{array}{l}\text { A positive correlation could be determined between Servant Leadership and helping as well as } \\
\text { creative behavior, which is supported by the promotion of the employees. }\end{array}$ & Neubert et al., 2008 \\
\hline Servant Leadership has a positive effect on the performance of an organization. & Choudhary et al., 2013; Huang et al., 2016 \\
\hline
\end{tabular}

With Servant Leadership being an employee-oriented leadership style, it is often compared to Transformational Leadership (Bass, 2000; Hamilton, 2008; Van Dierendonck, 2011).Even though both leadership styles can be regarded as transformational (Farling et al., 1999; Hamilton, 2008; Page and Wong, 2000), there is one major difference: Transformational Leadership feels mainly obliged to the organization and thus tries to bring the followers' goals in line with the goals of the organization (Parolini et al., 2009; Stone et al., 2004). Therefore, the growth of the employees only happens if it serves the organization's goals (Van Dierendonck, 2011). Servant Leadership, in contrast, is dedicated entirely to the needs of the individuals (Parolini et al., 2009; Stone et al., 2004) so that the organization's goals are sometimes actually deduced from the goals of the followers (Andersen, 2009). As a result of the comprehensive conceptual work and the empirical studies to prove the reliability and validity of the developed measurement model based on it, the further examination refers to the model developed by Van Dierendonck and Nuijten (2011).

\subsection{Models of IT project success}

Research in the field IT project success created a vast variety of models designed to register it and make it measurable (Harwardt, 2018). Even though different perspectives of IT project success are meanwhile taken into consideration, there is yet, despite corresponding demands, no model of IT project success that exclusively reflects the management's perspective of IT project success (Davis, 2014; Ika, 2009). Therefore, Harwardt, as a result of a qualitatively designed study, developed a model of IT project success that displays the management's perspective of the success of IT projects 
and thus closes the described gap (Harwardt; 2016, 2018). His latest model consisted of three success dimensions. The dimension Project management success includes everything related to the planning and execution of the IT project (e.g. adherence to schedule, budget and scope). Perception success rates the success of a project from the perspective of clients, end users and team members (e.g. satisfaction of end users). Result success assesses the success of the IT project by financial benefits (e.g. contribution to operating income) and strategical aspects (e.g. generation of strategical benefits) (Harwardt, 2018). In the following, this study refers to this model developed by Harwardt (2018), since its reliability and validity have already been demonstrated. Apart from that, it is a theoretically profound model based on findings derived from the analysis of interviews and written surveys of management members (Harwardt, 2016). Additionally, it can be stated that this part of the work investigates the effect of Servant Leadership on IT project success when being applied by management. Therefore, it seems obvious to examine how the application of Servant Leadership by management affects the success dimensions that were declared relevant by the management itself. This increases the practical relevance of this study for the management.

\subsection{Objectives of research}

This chapter tries to close the aforementioned gaps in literature. Therefore, the effect of leadership by management on the success of IT projects is being examined; this has not been undertaken so far (Clarke, 2012). Furthermore, the demand for further empirical research regarding Servant Leadership is supported (Parris \& Peachey, 2013). Thereby, this research clearly differs from similar works which are focused exclusively on the application of Servant Leadership by the project manager (Gwaya et al., 2014; Thompson, 2010) or define project success by the behavior of the employees (Krog \& Govender, 2015). In the course of this research a causal relation is assumed between the application of Servant Leadership by management and the success of an IT project. A causal relation is given if changes in an independent variable lead to changes in a dependent variable. Additionally, the changes in the independent variable have to temporally precede the changes in the dependent variable, and the independent variable is the only logical explanation for the observed changes in the dependent variable (Cook \& Campbell, 1979; Kenny, 1979). Since it is hardly possible to determine and control all cause variables, causality is already being assumed if the change in one variable is being caused by changing another variable (Blalock, 1985; Weiber \& Mühlhaus, 2014).

With leadership research, it is by now established to assume an impact of leadership, with occasional consideration of mediating variables or moderating variables on the individual performance of employees (House and Dessler, 1974; Martin et al., 2013; Miao et al., 2014; Mulki et al., 2015; Steward-Banks et al., 2015), the performance of a team (Amin and Kamal, 2016; Owens and Hekman, 2016; Schaubroeck et al., 2012), project success (Aga et al., 2016; Ayub et al., 2015; Kaminsky, 2012), or on the performance of an organization as a whole (Samad, 2012). As shown in Table 1, the field of Servant Leadership research also identifies and investigates effects of Servant Leadership on individual level (Harwiki, 2013; Jaramillo et al., 2009; Liden et al., 2008), on team level (Irving and Longbotham, 2007; Liden et al., 2008), on project level (Gwaya et al., 2014; Thompson, 2010) and on organizational level (Choudhary et al., 2013; Huang et al., 2016). Due to this broad acceptance of causality in leadership research, especially regarding leadership and team performance or leadership and project success, a causality between the application of Servant Leadership and the success of an IT project can be reasonably assumed.

In order to investigate the impact of Servant Leadership on IT project success, this research attends to the following question: Which effects do the different dimensions of Servant Leadership by Van Dierendonck and Nuijten (2011) have on the success dimensions of IT project success by Harwardt (2018), if Servant Leadership is applied by management in a project environment?

Besides the already presented theoretical relevance this work is highly significant for practice as well. This study shall hence show to what extent the behavior of management influences the success 
of an IT project. In this context, the model by Harwardt (2018) is particularly supportive as it captures those success dimensions which are regarded as relevant especially by management.

\section{Methodology}

\subsection{Research approach}

This research examines the impact of the dimensions of Servant Leadership on the success dimensions of an IT project by Harwardt (2018). To examine these impacts of latent variables structural equation modelling (SEM) is a widely recognized method. In order to estimates the effects within a theory-based model with SEM, one can use a variance- or a covariance-based approach (Weiber $\&$ Mühlhaus, 2014). This study focused on SEM with covariance analysis.

Before one can estimate the effects of latent variables, also known as factors or constructs, with SEM, measurement models of the latent variables have to be developed. A measurement models consist of observable manifestation of a factor which are often called items (Bollen, 2002; Weiber $\&$ Mühlhaus, 2014). After identifying reasonable measurement models a questionnaire was developed to gather the data required to estimate the effects via SEM. To gather the required data the survey platform SoSci Survey ${ }^{2}$ was used. The survey was exclusively conducted online because of the assumption that the target group of the study has a high online affinity due to their job.

Subsequently the data of the participants was downloaded from the platform and the returns were evaluated by the statistical software environment $R$ and the additional package $\operatorname{Lavaan}^{3}$ for structural equation modeling with the help of the Statistical Advisory Center of TU Dortmund. Within the scope of a confirmatory factor analysis the model quality was reviewed first; subsequently the impacts of the dimensions of Servant Leadership on the dimensions of IT project success by Harwardt (2018) were examined.

\subsection{Measurement model}

The model of Servant Leadership developed by Van Dierendonck and Nuijten consists of eight dimensions that comprise the skills and characteristics of a Servant Leader: Empowerment, Standing back, Accountability, Forgiveness, Courage, Authenticity, Humility and Stewardship (Van Dierendonck \& Nuijten, 2011). These dimensions were assigned 99 items, which were reduced to 30 items in the course of research. Due to the good values of relevant quality criteria like Root Mean Square Error of Approximation (RMSEA), Tucker-Lewis-Index, Standardized Root Mean Square Residual (SRMR) or Comparative Fit Index (see Table 2) a high quality of the model can be assumed. Values higher than 0.7 in determining Cronbach's Alpha for the individual dimensions of Servant Leadership prove a high internal consistency of the measurement model (Nunnally and Bernstein, 1994). The validity of the model was proven in the context of studies as well (Van Dierendonck \& Nuijten, 2011). The dimensions and their operationalization of the model of Servant Leadership by Van Dierendonck and Nuijten (2011) were thus included in the study on the impact of Servant Leadership on the success of IT projects (see appendix A).

The updated model by Harwardt (2018) achieves good values for the determined quality criteria as well (see Table 2), so that here, too, a high model quality of IT project success from a management perspective can be assumed. Moreover, the values of Cronbach's Alpha for the individual success criteria and success dimensions are higher than 0.7 , which proves a high internal consistency of the measurement model (Nunnally and Bernstein, 1994). Since Harwardt (2018) was able to demonstrate in his work not only the reliability but also the validity of his measurement model, the success

\footnotetext{
${ }^{2}$ see also www.soscisurvey.de, accessed 08-18-2018

${ }^{3}$ see also www.cran.r-project.org, accessed 08-18-2018
} 
dimensions and their corresponding operationalization were taken into account during further research (see appendix B).

Table 2

Quality criteria of the models

\begin{tabular}{llll}
\hline Definition & Abbreviation & Model Servant Leadership & Model Harwardt \\
\hline Chi-Square test statistic & $\chi^{2}$ & 623.500 & 982.867 \\
Degrees of freedom & df & 377 & 381 \\
Ratio $\chi^{2} / \mathrm{df}$ & - & 1.654 & 2.580 \\
Root Mean Square Error of Approximation & RMSEA & 0.050 & 0.053 \\
Tucker-Lewis Index & TLI & 0.920 & 0.947 \\
Root Mean Square Residual & RMR & Not indicated & 0.041 \\
Standardized Root Mean Square Residual & SRMR & 0.050 & 0.036 \\
Comparative Fit Index & CFI & 0.930 & 0.947 \\
\hline
\end{tabular}

Sources: Harwardt (2018); Van Dierendonck and Nuijten (2011)

\subsection{Sampling}

The target group of this survey were employees from the immediate environment of IT projects, who disposed of knowledge of both the internal view on a project and the cooperation in project as well as knowledge of the external view of the organization, the clients and the users. Additionally, the respondents needed to be capable of rating their supervising manager regarding the application of Servant Leadership dimensions. In order to prevent a self-evaluation of management and an overemphasis of individual skills, it was sought to enlist active IT project managers, IT project managers and ScrumMasters for participation in the survey. To ensure this, a corresponding control question was integrated into the questionnaire

Sampling was conducted in three steps. First, the personal network of the author was used for recruiting participants. Everybody who joined this study was also asked for other possible participants. Second, the questionnaire was circulated via $\mathrm{XING}^{4}$, a social network for professionals. Third, regional chapters of the Project Management Institute (PMI $)^{5}$ in Germany were also involved in this study.

This sampling strategy reaches out to professionals in Germany, Austria and Switzerland. Therefore, the questionnaire had to be in the German language which made is necessary to translate the items of the Servant Leadership questionnaire from English into German. To make sure that the translations are accurate and correct native speakers of both languages were consulted.

\subsection{Reliability of the measurement model}

Before one can start analyzing the effects the reliability and the validity of the model need to be checked. After starting to examine the reliability with a confirmatory factor analysis some problems occur.

1. The indicator reliability that determines the share of an item's variance, which is explained by the corresponding construct, was below the required threshold value of 0.4 (Bagozzi \& Baumgartner, 1994) for some of the items.

2. The determination of Cronbach's Alpha, which rates the internal consistency of the measurement models on construction level, also gives hints to optimization possibilities. The factor Stewardship did not exceed the threshold value of 0.7 (Nunnally and Bernstein, 1994). The internal consistency of the factors Empowerment, Standing back, Authenticity and Forgiveness may be enhanced by omitting items.

\footnotetext{
${ }^{4}$ see also www.xing.de, accessed 08-18-2018

${ }^{5}$ see also www.pmi.org, accessed 08-18-2018
} 
3. The average extracted variance rates the degree of variance of all items of a factor, that is explained by the factor itself. Here, they should not be lower than a threshold value of 0.5 (Fornell \& Larcker, 1981), which applies only for Stewardship. 
Therefore, optimizations were undertaken by omitting those items that stood out due to deficient values for indicator reliability or an optimization of Cronbach's Alpha. As Table 4 shows all the determined quality criteria, with exception of Stewardship are higher than the recommended threshold values. Only Cronbach's Alpha of 0.686 for Stewardship is below the threshold value of 0.7. Because of the short underrun and the fact that Stewardship fulfills all other quality criteria, the fact remains in the model.

Table 4

Value criteria on construction level of final effect model

\begin{tabular}{|c|c|c|c|c|c|c|}
\hline Factor & Item & $\begin{array}{l}\text { Indicator } \\
\text { reliability }\end{array}$ & $\begin{array}{l}\text { Cronbach's } \\
\text { Alpha } \\
\end{array}$ & $\begin{array}{l}\text { Average extracted } \\
\text { variance }\end{array}$ & $\begin{array}{l}\text { Factor reli- } \\
\text { ability }\end{array}$ & $\begin{array}{l}\text { Fornell/Larcker- } \\
\text { Criterion }\end{array}$ \\
\hline \multirow{6}{*}{ Empowerment } & SL01_01 & 0.626 & \multirow{6}{*}{0.923} & \multirow{6}{*}{0.674} & \multirow{6}{*}{0.925} & \multirow{6}{*}{ Fulfilled } \\
\hline & SL01_02 & 0.734 & & & & \\
\hline & SL01_03 & 0.797 & & & & \\
\hline & SL01_04 & 0.667 & & & & \\
\hline & SL01_12 & 0.587 & & & & \\
\hline & SL01_27 & 0.630 & & & & \\
\hline \multirow{2}{*}{ Standing back } & SL01_05 & 0.948 & \multirow{2}{*}{0.890} & \multirow{2}{*}{0.817} & \multirow{2}{*}{0.899} & \multirow{2}{*}{ Fulfilled } \\
\hline & SL01_13 & 0.686 & & & & \\
\hline \multirow{2}{*}{ Stewardship } & SL01_11 & 0.439 & \multirow{2}{*}{0.686} & \multirow{2}{*}{0.537} & \multirow{2}{*}{0.697} & \multirow{2}{*}{ Not fulfilled } \\
\hline & SL01_19 & 0.635 & & & & \\
\hline \multirow{5}{*}{ Humility } & SL01_10 & 0.804 & \multirow{5}{*}{0.913} & \multirow{5}{*}{0.681} & \multirow{5}{*}{0.914} & \multirow{5}{*}{ Not fulfilled } \\
\hline & SL01_18 & 0.518 & & & & \\
\hline & SL01_25 & 0.535 & & & & \\
\hline & SL01_29 & 0.787 & & & & \\
\hline & SL01_30 & 0.762 & & & & \\
\hline \multirow{3}{*}{ Authenticity } & SL01_09 & 0.572 & \multirow{3}{*}{0.829} & \multirow{3}{*}{0.622} & \multirow{3}{*}{0.831} & \multirow{3}{*}{ Fulfilled } \\
\hline & SL01_24 & 0.577 & & & & \\
\hline & SL01_28 & 0.717 & & & & \\
\hline \multirow{2}{*}{ Forgiveness } & SL01_07 & 0.877 & \multirow{2}{*}{0.805} & \multirow{2}{*}{0.698} & \multirow{2}{*}{0.820} & \\
\hline & SL01_23 & 0.518 & & & & Fulfilled \\
\hline & SL01_06 & 0.707 & & & & \\
\hline Accountability & SL01_14 & 0.824 & 0.907 & 0.769 & 0.909 & Fulfilled \\
\hline & SL01_22 & 0.775 & & & & \\
\hline Courage & SL01_08 & 0.453 & 0741 & 0614 & 0757 & Fulfilled \\
\hline courage & SL01_16 & 0.775 & 0.141 & 0.014 & 0.121 & Fummled \\
\hline & IT01_31 & 0.777 & & & & \\
\hline Project management success & IT01_33 & 0.895 & 0.921 & 0.805 & 0.925 & Fulfilled \\
\hline & IT01_35 & 0.744 & & & & \\
\hline Percention success & IT01_34 & 0.635 & 0865 & 0776 & 0873 & Fulfilled \\
\hline Perception success & IT01_36 & 0.918 & 0.003 & 0.170 & 0.013 & гummed \\
\hline Recult success & IT01_32 & 0.973 & 0850 & 0.770 & 0.868 & Fulfilled \\
\hline Result success & IT01_38 & 0.567 & 0.850 & 0.170 & 0.808 & \\
\hline
\end{tabular}

\subsection{Validity and measurement model}

Since the reliability of the measurement model could be verified, the next step is to examine the validity of the model. Content validity is given if the indicators semantically display their corresponding factor (Weiber \& Mühlhaus, 2014). This can be assumed, since, on the one hand, the comprehensive model is composed of two already validated models, and since, on the other hand, the measurement model was, in turn, validated by different researchers (Cronbach and Meehl, 1955). The additional high correlations of each factor's items, as to be looked up in appendix C, also argue for a high content validity (Hildebrandt, 1984). Construct validity is given, if the measurement of a factor "is not falsified by other constructs or systematical errors" (Weiber and Mühlhaus, 2014, p. 159). It is subsequently deduced by the nomological validity, the convergence valid- 
ity and the discriminant validity. Nomological validity is given, if the correlations between the constructs can be presented on a theoretically profound basis. In addition to a corresponding deduction of the model, the examination can be performed based on the model quality and the determined impacts (Bagozzi, 1979; Hildebrandt, 1984). As both the model quality (see Table 6) and the determined impacts (see Table 10) support the model, nomological validity can be assumed.

Convergence validity exists, if the measurement results of a factor are consistent when two different methods are applied (Fornell \& Larcker, 1981; Weiber \& Mühlhaus, 2014). With this often being rather difficult in practice, a different procedure has established itself (Weiber \& Mühlhaus, 2014): Convergence validity can be assumed, if the average extracted variance of each factor is higher than 0.5 (Fornell \& Larcker, 1981). According to Table 4, this applies for each individual factor.

Discriminant validity is given, if the measurements of different factors differ significantly (Fornell \& Larcker, 1981; Weiber \& Mühlhaus, 2014). This can be examined by the Fornell/Larcker-Criterion that relates the average extracted variance of a factor to its squared correlations with other factors. The average extracted variance should thereby always be higher than the squared correlations (Fornell \& Larcker, 1981). The only factors that do not fulfill this criterion are Stewardship and Humility. In order to prove the discriminant validity, it is additionally being examined how the correlations of a factor's items among themselves are related in comparison to the correlations of other factors. If at least half of all possible correlations of other factors' items are smaller than the correlations of the items among themselves, discriminant validity can be assumed (Campbell \& Fiske, 1959; Robey et al., 1993). Table 5 shows how large half of the possible correlations with other factors' items are and how many of the possible correlations are smaller than the correlations of items within a factor. As to be seen, at least $90 \%$ of the possible correlations are smaller than the correlations within the factors, so that discriminant validity can be assumed. Since by now both content validity as well as construct validity were proved, a reliable and valid measurement model is present in total.

Table 5

Examination of correlations of items of impact model

\begin{tabular}{lllll}
\hline Factor & $\begin{array}{l}\text { Number } \\
\text { Items }\end{array}$ & $\begin{array}{l}\text { Half of possible correlations } \\
\text { to other factors' items }\end{array}$ & $\begin{array}{l}\text { Smaller than correlations within } \\
\text { the factor }\end{array}$ & Percentage \\
\hline Empowerment & 6 & 78 & 143 & $91.667 \%$ \\
Standing back & 2 & 30 & 60 & $100.000 \%$ \\
Stewardship & 2 & 30 & 54 & $90.000 \%$ \\
Humility & 5 & 68 & 126 & $92.647 \%$ \\
Authenticity & 3 & 44 & 86 & $97.727 \%$ \\
Forgiveness & 2 & 30 & 60 & $100.000 \%$ \\
Accountability & 3 & 44 & 87 & $98.864 \%$ \\
Courage & 2 & 30 & 60 & $100.000 \%$ \\
Project management success & 3 & 44 & 87 & $98.864 \%$ \\
Perception success & 2 & 30 & 60 & $100.000 \%$ \\
Result success & 2 & 30 & 60 & $100.000 \%$ \\
\hline
\end{tabular}

\subsection{Fit model}

The determined values for the quality criteria of the model show that the model already fulfills most of the required criteria (see Table 6). The Root Mean Square Error of Estimation verifies if the current model approximates the present data. Here, a threshold value of 0.08 and smaller should be achieved, while zero reflects a complete approximation to reality (Brown \& Cudeck, 1993). With a determined value of 0.031 this criterion is appropriately fulfilled. The Root Mean Square Residual examines the discrepancies between the model-based and the empirical covariance matrix (Steiger, 1990). The scale has no upper limits, with small values pointing to slight deviations between the two (Jöreskog \& Sörbom, 1983). The value of 0.028 that was determined here shows slight deviations and hence a high approximation of the model to reality. The Standardized Root Mean Square Residual eliminates the problem of the open-ended scale and assumes values between zero and one. A threshold value of 0.08 should not be exceeded here (Hu \& Bentler, 1998). The determined value 
of 0.033 hence supports the previous findings. The Tucker-Lewis-Index and the Comparative Fit Index are incremental Fit-Indices. They compare the present model with an uncorrelated independence model. Both may assume values between zero and one, with a value close to one pointing to a substantial model (Bentler, 1990; Tucker \& Lewis, 1973). While a value of 0.95 and higher is often required as a threshold value for the Tucker-Lewis-Index (Hu \& Bentler, 1998), the Comparative Fit Index frequently uses a value of 0.9 and higher (Homburg \& Baumgartner, 1995). The threshold value of the Comparative Fit Index is over-run with 0.923 , as the threshold value of the TuckerLewis-Index is not over-run with 0.914 . Since the other quality criteria speak for an overall appropriate model, a good model fit can be assumed.

Table 6

Quality criteria of final comprehensive model

\begin{tabular}{lllc}
\hline Definition & Abbreviation & Model impacts & Threshold values \\
\hline Chi-Square test statistic & $\chi^{2}$ & 3067.970 & - \\
Degrees of freedom & Df & 2004 & - \\
Ratio $\chi^{2}$ df & - & 1.531 & $<=3$ \\
Root Mean Square Error of Approximation & RMSEA & 0.031 & $<=0.08$ \\
Root Mean Square Residual & RMR & 0.028 & Small values \\
Standardized Root Mean Square Residual & SRMR & 0.033 & $<=0.08$ \\
Tucker-Lewis Index & TLI & 0.914 & $>=0.95$ \\
Comparative Fit Index & CFI & 0.923 & $>=0.9$ \\
\hline
\end{tabular}

\section{Findings}

\subsection{Descriptive statistics}

The participants of the survey were IT project managers, IT project managers and ScrumMasters who were able to provide an internal and external view on their IT projects.

Table 7

Overview participants

\begin{tabular}{|c|c|c|c|}
\hline \multirow{3}{*}{$\stackrel{\grave{0}}{0}$} & Male & 398 & $70.1 \%$ \\
\hline & Female & 170 & $29.9 \%$ \\
\hline & Total & 568 & $100.0 \%$ \\
\hline \multirow{10}{*}{ 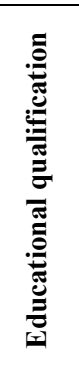 } & No graduation & 0 & $0.0 \%$ \\
\hline & General qualification for university entrance & 46 & $8.1 \%$ \\
\hline & Professional education & 65 & $11.4 \%$ \\
\hline & Bachelor (UAS) & 82 & $14.4 \%$ \\
\hline & Bachelor (University) & 54 & $9.5 \%$ \\
\hline & Diploma/master (UAS) & 130 & $22.9 \%$ \\
\hline & Diploma/master/magister (University) & 155 & $27.3 \%$ \\
\hline & Doctor's degree & 27 & $4.8 \%$ \\
\hline & None of the above & 9 & $1.6 \%$ \\
\hline & Total & 568 & $100.0 \%$ \\
\hline \multirow{6}{*}{ 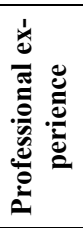 } & $<=5$ years & 92 & $16.2 \%$ \\
\hline & 6 to 15 years & 246 & $43.3 \%$ \\
\hline & 6 to 25 years & 136 & $23.9 \%$ \\
\hline & 26 to 35 years & 72 & $12.7 \%$ \\
\hline & $>35$ years & 22 & $3.9 \%$ \\
\hline & Total & 568 & $100.0 \%$ \\
\hline \multirow{6}{*}{ 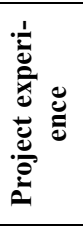 } & $<=5$ & 85 & $15.0 \%$ \\
\hline & $2=6$ to 10 & 130 & $22.9 \%$ \\
\hline & $3=11$ to 20 & 160 & $28.2 \%$ \\
\hline & $4=21$ to 30 & 87 & $15.3 \%$ \\
\hline & $5=>30$ & 106 & $18.7 \%$ \\
\hline & Total & 568 & $100.0 \%$ \\
\hline
\end{tabular}


As to be seen in Table 7, 568 participants could be enlisted, of whom 170, thus $29.9 \%$, were female. Besides a high number of participants with academic background, it can be registered that $83.8 \%$ of the participants disposed of long-term professional experience of six years and more and that $85.0 \%$ of the participants had a project experience of six and more projects.

Table 8 provides basic data on the organizations the participants of the survey were employed with. Despite the broad distribution including all professional sectors, it can be registered that the sector of IT and e-commerce is significantly over-represented in comparison to others. This is not very remarkable though, since it was sought to enlist especially those kinds of participants for the survey who are implementing IT projects. Only the sector health and social affairs is slightly under-represented with $3.3 \%$, though this may be due to the peculiarities of this sector.

\section{Table 8}

Overview organizations

\begin{tabular}{|c|c|c|c|}
\hline \multirow{10}{*}{ Sector } & Bank and insurance & 45 & $7.9 \%$ \\
\hline & Service & 45 & $7.9 \%$ \\
\hline & Media & 31 & $5.5 \%$ \\
\hline & IT and e-commerce & 253 & $44.5 \%$ \\
\hline & Health and social affairs & 19 & $3.3 \%$ \\
\hline & Trade and distribution & 65 & $11.4 \%$ \\
\hline & Administration and public services & 28 & $4.9 \%$ \\
\hline & Industry & 42 & $7.4 \%$ \\
\hline & Other & 40 & $7.0 \%$ \\
\hline & Total & 568 & $100.0 \%$ \\
\hline \multirow{3}{*}{ Con-tractor } & Yes & 240 & $42.3 \%$ \\
\hline & No & 328 & $57.7 \%$ \\
\hline & Total & 568 & $100.0 \%$ \\
\hline \multirow{7}{*}{$\begin{array}{l}\text { Number of } \\
\text { employees }\end{array}$} & $<10$ employees & 38 & $6.7 \%$ \\
\hline & 10 to 50 employees & 77 & $13.6 \%$ \\
\hline & 51 to 250 employees & 139 & $24.5 \%$ \\
\hline & 251 to 1000 employees & 144 & $25.4 \%$ \\
\hline & 1001 to 10.000 employees & 101 & $17.8 \%$ \\
\hline & $>10.000$ employees & 69 & $12.1 \%$ \\
\hline & Total & 568 & $100.0 \%$ \\
\hline \multirow{4}{*}{$\begin{array}{l}\text { Management } \\
\text { level }\end{array}$} & First-line management & 169 & $29.8 \%$ \\
\hline & Middle management & 263 & $46.3 \%$ \\
\hline & Senior management & 136 & $23.9 \%$ \\
\hline & Total & 568 & $100.0 \%$ \\
\hline
\end{tabular}

\subsection{Impacts of Servant Leadership on IT project success}

Table 10 contains the determined path coefficients and their corresponding $p$-values for the impact of Servant Leadership on the dimensions of IT project success. With a chosen significance level of $5 \%$ it can be registered, that only the Servant Leadership dimensions Authenticity, Accountability and Forgiveness assumed significant impacts since the p-values determined here were smaller than 0.05 . Due to the partly very high $\mathrm{p}$-values, other impacts are not considered in the following discussion.

\section{Discussion}

\subsection{Answer to research question}

By help of structural equation modeling it could be shown that Servant Leadership, if applied by management, can have a positive impact on the success of IT projects. In tangible terms, the Servant Leadership dimensions Authenticity, Accountability and Forgiveness have a positive impact on the three success dimensions Project management success, Perception success and Result success of an IT project (see Fig. 1). 
Table 10

Impact of Servant Leadership on IT project success

\begin{tabular}{|c|c|c|c|}
\hline Independent variable & Dependent variable & Standardized path coefficient & p-value \\
\hline \multirow{3}{*}{ Authenticity } & Result success & 0.206 & 0.017 \\
\hline & Project management success & 0.205 & 0.023 \\
\hline & Perception success & 0.113 & 0.209 \\
\hline \multirow{3}{*}{ Humility } & Perception success & -0.171 & 0.263 \\
\hline & Result success & -0.158 & 0.283 \\
\hline & Project management success & -0.127 & 0.408 \\
\hline \multirow{3}{*}{ Courage } & Project management success & 0.156 & 0.138 \\
\hline & Perception success & 0.107 & 0.301 \\
\hline & Result success & -0.016 & 0.871 \\
\hline \multirow{3}{*}{ Empowerment } & Perception success & 0.078 & 0.421 \\
\hline & Project management success & 0.061 & 0.529 \\
\hline & Result success & 0.046 & 0.621 \\
\hline \multirow{3}{*}{ Stewardship } & Project management success & -0.127 & 0.497 \\
\hline & Result success & 0.023 & 0.897 \\
\hline & Perception success & 0.004 & 0.983 \\
\hline \multirow{3}{*}{ Accountability } & Project management success & 0.152 & 0.010 \\
\hline & Result success & 0.133 & 0.018 \\
\hline & Perception success & 0.123 & 0.037 \\
\hline \multirow{3}{*}{ Forgiveness } & Result success & 0.141 & 0.046 \\
\hline & Project management success & 0.080 & 0.274 \\
\hline & Perception success & 0.039 & 0.596 \\
\hline \multirow{3}{*}{ Standing back } & Perception success & 0.062 & 0.364 \\
\hline & Project management success & -0.022 & 0.748 \\
\hline & Result success & 0.000 & 0.997 \\
\hline
\end{tabular}

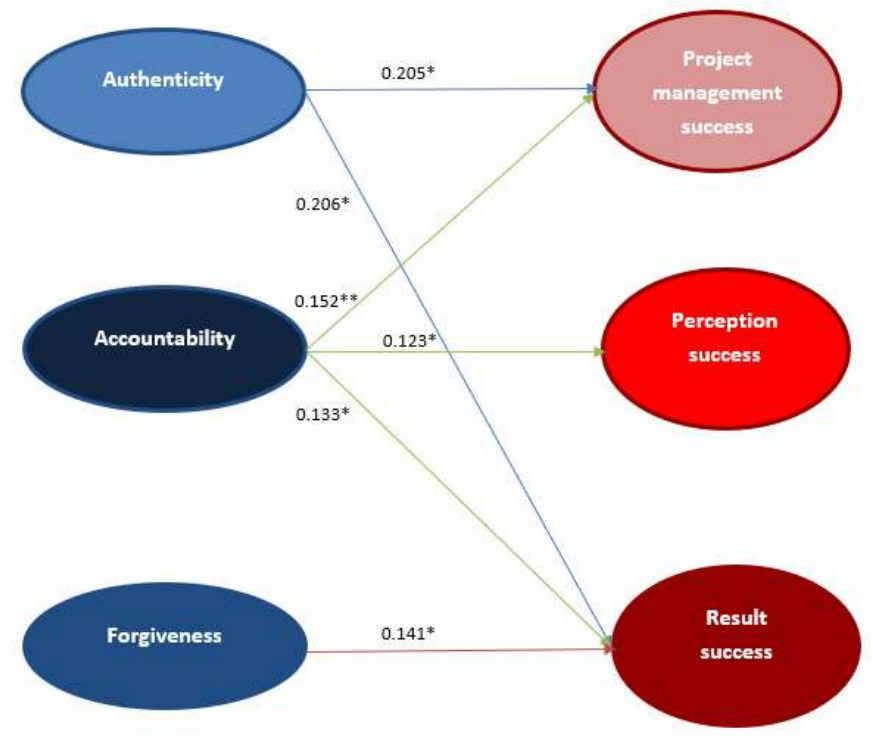

Fig. 1. Impacts of Servant Leadership

$(* *=$ very significant with $\mathrm{p}$-value $>0.001$ and $\leq 0.01 ; *=$ significant with $\mathrm{p}$-value $>0.01$ and $\leq 0.05)$

Here, Authenticity positively affects the dimensions Project management success and Result success. Authenticity describes the ability to have an appearance that is consistent with one's feelings and thoughts (Van Dierendonck and Nuijten, 2011). If leaders are authentic and genuine, then they 
are trusted (George et al., 2007). Trust, in turn, has a positive impact on the attitude towards the job, on the performance of a team, on cooperation and on the commitment to the organization (Dirks, 2000; Dirks and Skarlicki, 2009; Jones and George, 1998; Lewicki et al., 2006; Liden et al., 2014; Schaubroeck et al., 2011). These factors eventually contribute to an efficient project implementation and an enhanced project result. The Servant Leadership dimension Accountability has a positive impact on the three success dimensions Project management success, Perception success and Result success, if corresponding behavior is lived by management. A leader possessing this characteristic assigns responsibility to the followers, thus rendering them accountable for the results (Konczak et al., 2000). Accountability is thereby regarded as an important instrument of positive and effective leadership (Van Dierendonck \& Nuijten, 2011), so that positive impacts on the dimensions of IT project success, especially on the team's perception and an efficient project implementation, can be expected. This, again, can lead to an enhanced project result. Forgiveness describes the ability to forgive mistakes and to not pursue them any further. By this, a trustworthy environment for the cooperation of leader and followers is generated (Van Dierendonck and Nuijten, 2011). Forgiveness has a positive impact on the Result success. If leaders allow employees to make mistakes, a trustworthy environment for employees can develop (Ferch, 2005), which has influence on the Result success as well (Dirks, 2000; Dirks and Skarlicki, 2009; Jones and George, 1998; Lewicki et al., 2006; Liden et al., 2014).

Although literature shows a positive impact of Humility, Courage, Empowerment, Standing back and Stewardship on project success (Caldwell et al., 2008; De Cremer, 2006; Grosse, 2007), this study cannot confirm these effects. The reasons for this could be that this study was only conducted in Germany, Austria and Switzerland, so results may differ from studies conducted in other cultural areas.

\subsection{Limitations}

First, the study is subject to the limitation of having been conducted only locally in German-speaking regions with participants from Germany, Austria and Switzerland. Transferring the results into an international context is hence not immediately possible. Moreover, it has to be stated that neither moderating nor mediating impacts (e.g. trust) were considered in the examined structural equation model. Additionally, there may be other factors influencing the success of an IT project, e.g. the experience of the project manager or the skills of the project team. A common-method bias cannot be fully excluded due to type and structure of the survey (Podsakoff \& Organ, 1986).

\subsection{Conclusion and recommendations for further research}

This paper shows the positive impact of the dimensions of Servant Leadership on the success dimensions of an IT project:

1. Authenticity affects Project management success and Result success;

2. Accountability affects Project management success, Perception success and Result success;

3. Forgiveness affects Result success.

These findings are highly important to the management because now they have a toolbox of how to act and to behave that can lead to successful projects. No significant impacts on the success dimensions of an IT project could be proven for Humility, Courage, Empowerment, Standing back and Stewardship. This is remarkable, since literature underlines the positive impact of these characteristics (Caldwell et al., 2008; De Cremer, 2006; Grosse, 2007). It is hence interesting to examine in detail why these characteristics of a Servant Leader have no impact on the success dimensions of IT projects. The explanation of the causal relations between the dimensions of Servant Leadership and the success dimensions of an IT project indicates that mediating effects like trust exist, which should be examined more closely. Furthermore, it is possible that moderating variables exist which 
influence the strength of the impact of the Servant Leadership's dimensions on the success dimensions of IT project success.

To conclude, a further examination of factors influencing the success of IT projects is necessary. This includes a detailed exploration of the causes of the already identified impacts on IT projects. On the other hand, other potentially influencing factors should be examined. Since this research was only conducted in German-speaking regions, a transfer into an international context is desirable.

\section{References}

Aga, D. A., Noorderhaven, N., \& Vallejo, B. (2016). Transformational leadership and project success: The mediating role of team-building. International Journal of Project Management, 34(5), 806-818.

Amin, S., \& Kamal, Y. (2016). Impact of natural born leader qualities on the project team performance: The influences of demographics (gender and age). International Journal of Management, Accounting and Economics, 3, 306-318.

Ayub, A. (2015). Impact of Project Leadership Facets on Project Outcome. Acta Universitatis Danubius. Economica, 11(4).

Babakus, E., Yavas, U., \& Ashill, N. J. (2010). Service worker burnout and turnover intentions: Roles of person-job fit, servant leadership, and customer orientation. Services Marketing Quarterly, 32(1), 17-31.

Bagozzi, R. P. (1979). The role of measurement in theory construction and hypothesis testing: toward a holistic model. Conceptual and Theoretical Developments in Marketing, 15, 32.

Bagozzi, R. P., \& Baumgartner, H. (1994). The evaluation of structural equation models and hypothesis testing. Principles of marketing research, 1(10), 386-422.

Barbuto Jr, J. E., \& Wheeler, D. W. (2006). Scale development and construct clarification of servant leadership. Group \& Organization Management, 31(3), 300-326.

Bass, B. M. (2000). The future of leadership in learning organizations. Journal of leadership studies, 7(3), 18-40.

Bass, B. M., \& Bass, R. (2009). The Bass handbook of leadership: Theory, research, and managerial applications. Simon and Schuster.

Bentler, P. M. (1990). Comparative fit indexes in structural models. Psychological bulletin, 107(2), 238.

Blalock, J. (2017). Causal models in the social sciences. Routledge.

Bollen, K. A. (2002). Latent variables in psychology and the social sciences. Annual review of psychology, 53(1), 605-634.

Browne, M. W., \& Cudeck, R. (1993). Alternative ways of assessing model fit. Sage focus editions, 154, 136-136.

Caldwell, C., Hayes, L. A., Bernal, P., \& Karri, R. (2008). Ethical stewardship-implications for leadership and trust. Journal of business ethics, 78(1-2), 153-164.

Cerit, Y. (2009). The effects of servant leadership behaviours of school principals on teachers' job satisfaction. Educational Management Administration \& Leadership, 37(5), 600-623.

Cerit, Y. (2010). The effects of servant leadership on teachers' organizational commitment in primary schools in Turkey. International Journal of Leadership in Education, 13(3), 301-317.

Campbell, D. T., \& Fiske, D. W. (1959). Convergent and discriminant validation by the multitraitmultimethod matrix. Psychological bulletin, 56(2), 81.

Choudhary, A. I., Akhtar, S. A., \& Zaheer, A. (2013). Impact of transformational and servant leadership on organizational performance: A comparative analysis. Journal of business ethics, $116(2), 433-440$.

Chung, J. Y., Jung, C. S., Kyle, G. T., \& Petrick, J. F. (2010). Servant Leadership and Procedural Justice in the US National Park Service: The Antecedents of Job Satisfaction. Journal of Park \& Recreation Administration, 28(3). 
Clarke, N. (2012). Leadership in projects: what we know from the literature and new insights. Team Performance Management: An International Journal, 18(3/4), 128-148.

Cook, T. D., \& Campbell, D. T. (1979). The design and conduct of true experiments and quasiexperiments in field settings. In Reproduced in part in Research in Organizations: Issues and Controversies. Goodyear Publishing Company.

Cronbach, L. J., \& Meehl, P. E. (1955). Construct validity in psychological tests. Psychological bulletin, 52(4), 281.

Davis, K. (2014). Different stakeholder groups and their perceptions of project success. International journal of project management, 32(2), 189-201.

De Cremer, D. (2006). Affective and motivational consequences of leader self-sacrifice: The moderating effect of autocratic leadership. The Leadership Quarterly, 17(1), 79-93.

Dirks, K. T. (2000). Trust in leadership and team performance: Evidence from NCAA basketball. Journal of applied psychology, 85(6), 1004.

Dirks, K. T., \& Skarlicki, D. P. (2009). The relationship between being perceived as trustworthy by coworkers and individual performance. Journal of Management, 35(1), 136-157.

Ehrhart, M. G. (2004). Leadership and procedural justice climate as antecedents of unit-level organizational citizenship behavior. Personnel psychology, 57(1), 61-94.

Farling, M. L., Stone, A. G., \& Winston, B. E. (1999). Servant leadership: Setting the stage for empirical research. Journal of Leadership Studies, 6(1-2), 49-72.

Ferch, S. R. (2003). Servant-leadership, forgiveness, and social justice. Greenleaf Center for Servant-Leadership.

Fornell, C., \& Larcker, D. F. (1981). Evaluating structural equation models with unobservable variables and measurement error. Journal of marketing research, 18(1), 39-50.

Garber, J. S., Madigan, E. A., Click, E. R., \& Fitzpatrick, J. J. (2009). Attitudes towards collaboration and servant leadership among nurses, physicians and residents. Journal of Interprofessional Care, 23(4), 331-340.

George, B., Sims, P., McLean, A. N., \& Mayer, D. (2007). Discovering your authentic leadership. Harvard business review, 85(2), 129.

Giampetro-Meyer, A., Brown, S. T., Browne, M. N., \& Kubasek, N. (1998). Do we really want more leaders in business?. Journal of Business Ethics, 17(15), 1727-1736.

Greenleaf, R. K. (2008). The servant as leader.

Grosse, D. (2007). Leadership in R\&D projects. Creativity and Innovation Management, 16(4), 447-456.

Gwaya, A. O., Masu, S. M., \& Oyawa, W. O. (2014). The role of servant leadership in project management in Kenya. International journal of soft computing and engineering, 2231-2307.

Hale, J. R., \& Fields, D. L. (2007). Exploring servant leadership across cultures: A study of followers in Ghana and the USA. Leadership, 3(4), 397-417.

Harwardt, M. (2016). Criteria of successful IT projects from management's perspective. Open Journal of Information Systems (OJIS), 3(1), 29-54.

Harwardt, M. (2018). IT Project Success from the Management Perspective-A Quantitative Evaluation. Open Journal of Information Systems (OJIS), 5(1), 24-52.

Harwiki, W. (2013). Influence of servant leadership to motivation, organization culture, organizational citizenship behavior (OCB), and employee's performance in outstanding cooperatives East Java Province, Indonesia. OSR Journal of Business and Management, 8(5), 50-58.

Hesse, H. (2003). The journey to the east: A novel. Macmillan.

Hildebrandt, L. (1984). Kausalanalytische Validierung in der Marketingforschung. Marketing: Zeitschrift für Forschung und Praxis, 41-51.

Homburg, C., \& Baumgartner, H. (1995). Beurteilung von Kausalmodellen. Bestandsaufnahme und Anwendungsempfehlungen. Marketing ZfP, 17(3), 162-176.

House, R. J., \& Dessler, G. (1974). The path-goal theory of leadership: Some post hoc and a priori tests. Contingency approaches to leadership, 29, 55.

Hu, L. T., \& Bentler, P. M. (1998). Fit indices in covariance structure modeling: Sensitivity to underparameterized model misspecification. Psychological methods, 3(4), 424. 
Huang, J., Li, W., Qiu, C., Yim, F. H. K., \& Wan, J. (2016). The impact of CEO servant leadership on firm performance in the hospitality industry. International Journal of Contemporary Hospitality Management, 28(5), 945-968.

Ika, L. A. (2009). Project success as a topic in project management journals. Project Management Journal, 40(4), 6-19.

Irving, J. A., \& Longbotham, G. J. (2007). Team effectiveness and six essential servant leadership themes: A regression model based on items in the organizational leadership assessment. International Journal of Leadership Studies, 2(2), 98-113.

Jaramillo, F., Grisaffe, D. B., Chonko, L. B., \& Roberts, J. A. (2009). Examining the impact of servant leadership on sales force performance. Journal of Personal Selling \& Sales Management, 29(3), 257-275.

Jessen, S. A. (2002). Business by projects. Universitetsforlaget.

Jones, G. R., \& George, J. M. (1998). The experience and evolution of trust: Implications for cooperation and teamwork. Academy of management review, 23(3), 531-546.

Jöreskog, K. G., \& Sörbom, D. (1983). LISREL: Analysis of linear structural relationships by the method of maximum likelihood, user's guide, versions V and VI. Chicago: Scientific Software.

Joseph, E. E., \& Winston, B. E. (2005). A correlation of servant leadership, leader trust, and organizational trust. Leadership \& Organization Development Journal, 26(1), 6-22.kamin

Kaminsky, J. B. (2012). Impact of nontechnical leadership practices on IT project success. Journal of Leadership Studies, 6(1), 30-49.

Kenny, D. A. (1979). Correlation and causality. New York: Wiley, 1979.

Krog, C., \& Govender, K. (2015, October). Servant leadership and project management: Examining the effects of leadership style on project success. In European Conference on Management, Leadership \& Governance (pp. 201-210). Academic Conferences International Limited.

Konczak, L. J., Stelly, D. J., \& Trusty, M. L. (2000). Defining and measuring empowering leader behaviors: Development of an upward feedback instrument. Educational and Psychological measurement, 60(2), 301-313.

Laub, J. A. (1999). Assessing the servant organization. Florida Atlantic University.

Lech, P. (2013). Time, budget, and functionality?-IT project success criteria revised. Information Systems Management, 30(3), 263-275.

Lewicki, R. J., Tomlinson, E. C., \& Gillespie, N. (2006). Models of interpersonal trust development: Theoretical approaches, empirical evidence, and future directions. Journal of management, 32(6), 991-1022.

Liden, R. C., Wayne, S. J., Zhao, H., \& Henderson, D. (2008). Servant leadership: Development of a multidimensional measure and multi-level assessment. The leadership quarterly, 19(2), 161177.

Liden, R. C., Wayne, S. J., Liao, C., \& Meuser, J. D. (2014). Servant leadership and serving culture: Influence on individual and unit performance. Academy of Management Journal, 57(5), 14341452.

Martin, S. L., Liao, H., \& Campbell, E. M. (2013). Directive versus empowering leadership: A field experiment comparing impacts on task proficiency and proactivity. Academy of Management Journal, 56(5), 1372-1395.

Mayer, D. M., Bardes, M., \& Piccolo, R. F. (2008). Do servant-leaders help satisfy follower needs? An organizational justice perspective. European Journal of Work and Organizational Psychology, 17(2), 180-197.

McCuddy, M. K., \& Cavin, M. C. (2008). Fundamental moral orientations, servant leadership, and leadership effectiveness: An empirical test. Review of Business Research, 8(4), 107-117.

Melrose, K. (1998). Putting servant-leadership into practice. Insights on leadership: Service, stewardship, spirit, and servant-leadership, 279-296.

Miao, Q., Newman, A., \& Huang, X. (2014). The impact of participative leadership on job performance and organizational citizenship behavior: Distinguishing between the mediating effects of affective and cognitive trust. The International Journal of Human Resource Management, 25(20), 2796-2810. 
Mulki, J. P., Caemmerer, B., \& Heggde, G. S. (2015). Leadership style, salesperson's work effort and job performance: the influence of power distance. Journal of Personal Selling \& Sales Management, 35(1), 3-22.

Neubert, M. J., Kacmar, K. M., Carlson, D. S., Chonko, L. B., \& Roberts, J. A. (2008). Regulatory focus as a mediator of the influence of initiating structure and servant leadership on employee behavior. Journal of applied psychology, 93(6), 1220.

Nunnally, J., \& Bernstein, I. (1994). Psychometric Theory 3rd edition (MacGraw-Hill, New York).

Owens, B. P., \& Hekman, D. R. (2016). How does leader humility influence team performance? Exploring the mechanisms of contagion and collective promotion focus. Academy of Management Journal, 59(3), 1088-1111.

Page, D., \& Wong, T. P. (2000). A conceptual framework for measuring servant leadership. The human factor in shaping the course of history and development, 69-110.

Parolini, J., Patterson, K., \& Winston, B. (2009). Distinguishing between transformational and servant leadership. Leadership \& Organization Development Journal, 30(3), 274-291.

Parris, D. L., \& Peachey, J. W. (2013). A systematic literature review of servant leadership theory in organizational contexts. Journal of business ethics, 113(3), 377-393.

Podsakoff, P. M., \& Organ, D. W. (1986). Self-reports in organizational research: Problems and prospects. Journal of management, 12(4), 531-544.

Robey, D., Smith, L. A., \& Vijayasarathy, L. R. (1993). Perceptions of conflict and success in information systems development projects. Journal of Management Information Systems, 10(1), 123-140.

Russell, R. F., \& Gregory Stone, A. (2002). A review of servant leadership attributes: Developing a practical model. Leadership \& Organization Development Journal, 23(3), 145-157.

Samad, S. (2012). The influence of innovation and transformational leadership on organizational performance. Procedia-Social and Behavioral Sciences, 57, 486-493.

Schaubroeck, J., Lam, S. S., \& Peng, A. C. (2011). Cognition-based and affect-based trust as mediators of leader behavior influences on team performance. Journal of Applied Psychology, 96(4), 863.

Schwalbe, K. (2015). Information technology project management. Cengage Learning.

Sendjaya, S., \& Sarros, J. C. (2002). Servant leadership: Its origin, development, and application in organizations. Journal of Leadership \& Organizational Studies, 9(2), 57-64.

Smith, B. N., Montagno, R. V., \& Kuzmenko, T. N. (2004). Transformational and servant leadership: Content and contextual comparisons. Journal of Leadership \& Organizational Studies, 10(4), 80-91.

Spears, L. C. (1995). Reflections on leadership: How Robert K. Greenleaf's theory of servant-leadership influenced today's top management thinkers (No. 658.4092 R333r). Wiley.

Spears, L. C., \& Lawrence, M. (Eds.). (2016). Practicing servant-leadership: Succeeding through trust, bravery, and forgiveness. John Wiley \& Sons.

Steiger, J. H. (1990). Structural model evaluation and modification: An interval estimation approach. Multivariate behavioral research, 25(2), 173-180.

Stewart-Banks, B., Kuofie, M., Hakim, A., \& Branch, R. (2015). Education Leadership Styles Impact on Work Performance and Morale of Staff. Journal of Marketing \& Management, 6(2).

Gregory Stone, A., Russell, R. F., \& Patterson, K. (2004). Transformational versus servant leadership: A difference in leader focus. Leadership \& Organization Development Journal, 25(4), 349361.

Taylor, T., Martin, B. N., Hutchinson, S., \& Jinks, M. (2007). Examination of leadership practices of principals identified as servant leaders. International journal of leadership in education, 10(4), 401-419.

Thompson, K. N. (2010). Servant-leadership: An effective model for project management. Unpublished doctoral dissertation). Capella University, Minneapolis, MN.

Tucker, L. R., \& Lewis, C. (1973). A reliability coefficient for maximum likelihood factor analysis. Psychometrika, 38(1), 1-10. 
Van Dierendonck, D. (2011). Servant leadership: A review and synthesis. Journal of management, 37(4), 1228-1261.

Van Dierendonck, D., \& Nuijten, I. (2011). The servant leadership survey: Development and validation of a multidimensional measure. Journal of business and psychology, 26(3), 249-267.

Walumbwa, F. O., Hartnell, C. A., \& Oke, A. (2010). Servant leadership, procedural justice climate, service climate, employee attitudes, and organizational citizenship behavior: a cross-level investigation. Journal of applied psychology, 95(3), 517.

Weiber, R., \& Mühlhaus, D. (2014). Strukturgleichungsmodellierung: Eine anwendungsorientierte Einführung in die Kausalanalyse mit Hilfe von AMOS, SmartPLS und SPSS. Springer-Verlag.

\section{Appendix A - Questionnaire Servant Leadership}

The following items were used in the original study conducted by Van Dierendonck and Nuijten (2011). They were also used in the study at hand. The "_“ marks negatively phrased items. The items were rated by the participants with the help of a six-stage Likert scaling. 1 stood for complete refusal of the statement, 6 stood for full approval.

\section{Empowerment}

- SL01_1: My manager gives me the information I need to do my work well.

- SL01_2: My manager encourages me to use my talents.

- SL01_3: My manager helps me to further develop myself.

- SL01_4: My manager encourages his/her staff to come up with new ideas.

- SL01_12: My manager gives me the authority to take decisions which make work easier for me.

- SL01_20: My manager enables me to solve problems myself instead of just telling me what to do.

- SL01_27: My manager offers me abundant opportunities to learn new skills.

$\underline{\text { Standing back }}$

- SL01_5: My manager keeps himself/herself in the background and gives credits to others.

- SL01_13: My manager is not chasing recognition or rewards for the things he/she does for others.

- SL01_21: My manager appears to enjoy his/her colleagues' success more than his/her own.

Accountability

- SL01_6: My manager holds me responsible for the work I carry out.

- SL01_14: I am held accountable for my performance by my manager.

- SL01_22: My manager holds me and my colleagues responsible for the way we handle a job.

Forgiveness

- SL01_7: My manager keeps criticizing people for the mistakes they have made in their work (-).

- SL01_15: My manager maintains a hard attitude towards people who have offended him/her at work (-).

- SL01_23: My manager finds it difficult to forget things that went wrong in the past (-). Courage

- SL01_8: My manager takes risks even when he/she is not certain of the support from his/her own manager.

- SL01_16: My manager takes risks and does what needs to be done in his/her view.

Authenticity

- SL01_9: My manager is open about his/her limitations and weaknesses.

- SL01_17: My manager is often touched by the things he/she sees happening around him/her.

- SL01_24: My manager is prepared to express his/her feelings even if this might have undesirable consequences.

- $\quad$ SL01_28: My manager shows his/her true feelings to his/her staff. Humility

- SL01_10: My manager learns from criticism.

- SL01_18: My manager tries to learn from the criticism he/she gets from his/her superior.

- SL01_25: My manager admits his/her mistakes to his/her superior.

- SL01_29: My manager learns from the different views and opinions of others.

- SL01_30: If people express criticism, my manager tries to learn from it.

Stewardship 
- SL01_11: My manager emphasizes the importance of focusing on the good of the whole.

- SL01_19: My manager has a long-term vision.

- SL01_26: My manager emphasizes the societal responsibility of our work.

\section{Appendix B - Questionnaire Project success}

The following statements are extracted from the questionnaire on IT project success and were supposed to be rated by the participants with the help of a five-stage Likert scaling. 1 stood for complete refusal of the statement, 5 stood for full approval.

Project management success

- IT01_31: The project planning is perceived as successful.

- IT01_33: The project management is highly efficient.

- IT01_35: The project is conducted without serious incidents.

Perception success

- IT01_34: All stakeholders are satisfied with the project.

- IT01_36: The stakeholders have a positive perspective on the project.

$\underline{\text { Result success }}$

- IT01_32: The project result is rated as successful.

- IT01_38: The project result complies with the goals related to it.

\section{Appendix C - Correlations of items}

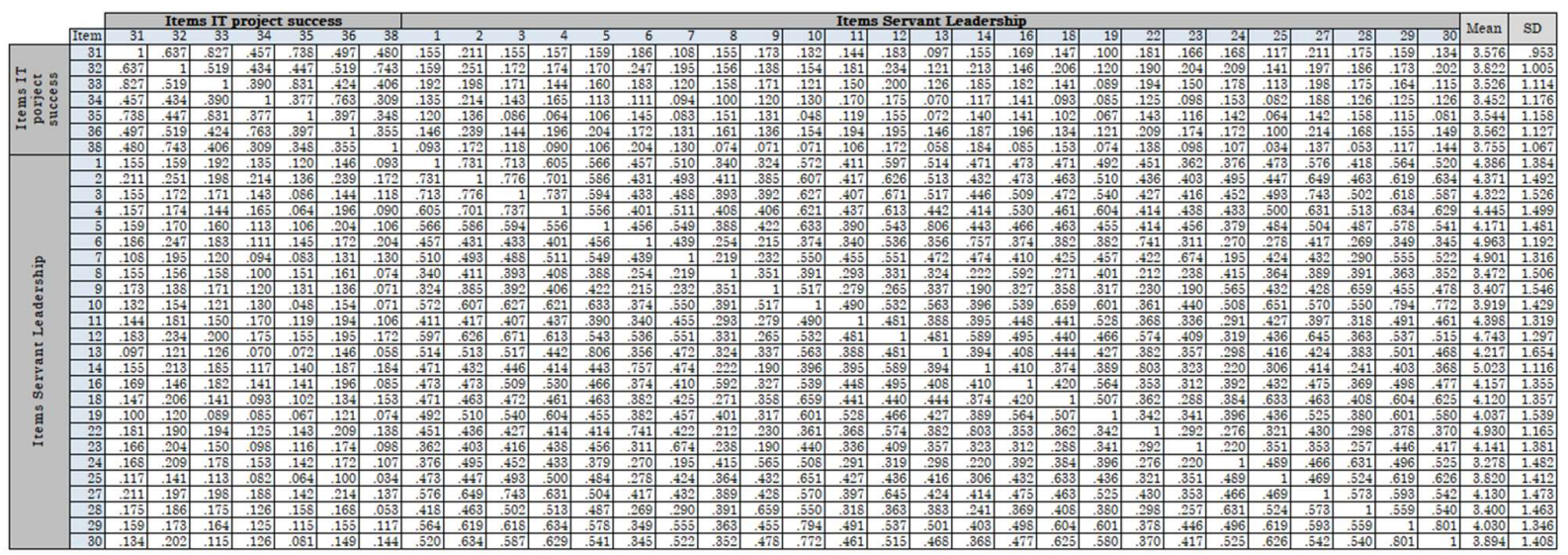

Figure C.1. Correlations of items

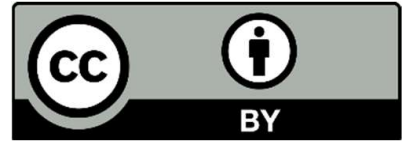

(C) 2020 by the authors; licensee Growing Science, Canada. This is an open access article distributed under the terms and conditions of the Creative Commons Attribution (CC-BY) license (http://creativecommons.org/licenses/by/4.0/). 